\title{
Intertextual Review of a Once-Banned Author's Dramatical Work
}

\section{PhD Candidate, Besa Shingjergji}

\author{
EU "Aleksandër Xhuvani, Faculty of Human Sciences \\ besashingjergji@gmail.com
}

\section{Doi:10.5901/mjss.2013.v4n9p405}

\begin{abstract}
Etëhem Haxhiademi is one of the most distinguished creators of the Albanian Tragedy. He is a classical tragedian appearing in the modern phase of the Albanian literature. The artistic geography of Haxhiademi's tragedies seizes wide spaces, even crossing inter-balkanic borders. His dramatic work, built according to the models of the classical tragedy and evolving antiquity or mediEvel subjects and even those of the biblical pre-history, became function of the concerning issues which found its parallels in the phenomenon, ideas and problems featuring the reality of the time they were written. Haxhiademi's literary work, as one of the variants of the literary system, has been built on traces, codes and literary traditions created in the course of time in the Albanian, national literary heritage as well as in the inter-balkanic and international inheritance. This makes his work to be intertextual rather than completely independent. In this study, the rereading of the dramatic work of one of the most outstanding writers of the 30s in the XX century, Etëhem Haxhiademi's, will be done by presenting his work in rapport with texts belonging to the same system: the literary ones. In these terms, understanding the playwright's work derives from the intertextuality as well as from the contemporary readers' re-reading, who, with a cold logic will try to place the 45-year politically imprisoned writer, into the true system of the literary values. The study made use of comparison, analyses and synthesis methods.
\end{abstract}

Keywords: intertextual review, banned author, classical tragedian, author's rereading, author's re-appraisal.

\section{Introduction}

In many cases texts can be understood solely by referring to previous texts persisting into the addressee's memory, or purely by basing on a cognitive culture in a certain domain. The notion of intertextuality in the structuralist and poststructuralist theory has not wholly been understood in the same way.

However, the common concept held by all the theoreticians dealing with this way of interpretation is the recognition of the literary text's dependence on all the texts persisting previously. According to this point of view, each literary text is not an isolated evolvement instead it is an absorption and transformation of another one. By challenging the traditional notions, these theories understand intertextuality as: "...a shift of one or two diacritical systems into another or into several others". (Kristeva, J. 1999). However, the intertextuality concept was used by poststructuralists to oppose the viewpoint protecting the consistent meaning of the literary text as well as its objective interpretation. While the structuralist critique believed that Saussurean linguistics supported literary criticism to become objective and scientific, the poststructuralist criticism has been trying to argue that because of the inconsistency of the literature, its interpretation is product of the subjective reception and appraisal. According to them, there is no consistent literary text as far as the intertextual nature of the literary work leads the readers to a newer relationship therefrom. The notion of intertextuality brought a new understanding about the ways to apprehend literature, the authorship and reading. What intertextuality brings in the literary studies is the meaning of a literary text as an intertext in rapport with previous works, at the same time its recognition as multi-semantic, with blurred boundaries, open to the readers according to the viewpoints held by Kristeva, Roland Bart, etc. (Dado F 2006). One of the problems persisting with intertextuality is linked with the text's allusion or with the way it is refers to the other known texts, relevant to the principle that all those who write texts can refer to the previously known texts. (De Beaugrande, R.A\& Dressler, W. U.1994). Viewpoints about intertextuality appear in several variants:

1 As a research on the relations between the new text and the other previous ones.

2 As a research on the general patterns of a literary work, suchlike the gender, the shaping of the motifs, subjects etc.

3 Setting parallels with other social and conventional narration, (a way evolved especially by the poststructuralists, new Marxists, the feminist criticism, etc). 
4 A research on the complicated relationships created among the text and the readings following it. (Onega, S., \& Landa, G. A.J. 1996)

\section{Intertextuality in E Haxhiademi's dramatic work}

A question is naturally raised: what aspect has Etëhem Haxhiademi's work been researched? The author, whose literary work has been focus of this research, wrote his works in the early XX century. He was a well-known, cultivated personality, a connoisseur of many foreign languages such as Latin, Greek, Italian, French, German, English and Russian, as well as an expert of the world literature masterpieces.

The intention to review the banned author's dramatic work from the intertextual point of view is not an analysis on its own but conclusions regarding the rapports of his tragedies with other literary texts belonging to our diacritical literary system which will reveal real values featuring his work, on its own and on the background of the contemporary literature, as well as revealing the rapport of his literary work with the present-day readers.

While referring to $\mathrm{J}$. Kristeve's assertion that the literary text is not an isolated composition, rather, it is a compilation of the cultural textuality; E. Haxhiademi's work can also be seen in relations with other texts belonging to such a context. His tragedies contain ideological structures expressing the spirit of the coetaneous society. Mikhail Bakhtin's dialogism helped the processing of the literary intertextuality. According to him, self and the ideology are in dialogical relationships, the individual and the social language both determine each-other and, as every individual colloquialism they pass through the social narration. Precisely this theory of Bakhtin guides us specifically to the interpretation of the literary text, therefore, to its apprehension as a dialogic process, not simply as a narrative apprehension comment, (i.e. the Abel and Scanderbeg tragedies).

Therefore these tragedies are intertextual in the background of the coetaneous society's ideology. They are intertext of a social and historical text. In terms of intertextual viewpoint, the recognition of those works is as internal ( $E$ Haxhiademi's individual way of artistic realization) as it is external, (in the already pre-existing literary texts in rapports with which every E. Haxhiademi's text is intertextual). In this case intertextuality is searched by means of the narrative and ideological forms, both characterizing narration in the society.

The traditional way of historical interpretation of E. Haxhiademi's work, considers his dramatic text as effect of certain historic and social circumstances. Other than this, the intertextual point of view avoids the notion of the external sources and it focuses on revealing the rapports between internal diacritical structures and the social-cultural ones. Such words as: anger, in your misery, injured heart, brother, enemy, die to save me, evil spirit, your envy, express inner social conflicts, in the text structure they have been considered in certain rapports with the general social text. By reading the author's dramatic text we would not intend only to simply find the reference to these words or other forms of narration with the external world but with the diacritical literary system, by means which such texts have been created. This viewpoint sets new rapports between the text and the context. Although at "Scanderbeg" or "Abel" the context explicates the text, it is very distinctive from the latter. The intertext of this prose is the existence of the text, ("Skanderbeg" dhe "Abel") within another text, not simply the origin of the prose thereof. Undoubtedly, Haxhiademi's texts contain ideological structures of the Albanian society within themselves, expressed into their narration, but their intertextual dimension should be seen in the persistent literary background. They do not reflect isolated objects, but the realization of Albania's historic and cultural textuality. The author's contemporary critics have asserted that the tragedy "Scanderbeg" was written according to the ancient Greek tragedy model. Until the period Haxhiademi published the tragedy "Scanderbeg" many literary works had been written for this figure in the Albanian literature, (1935), and the world literature had also recognized more that 100 artistic creations, in 21 languages. In centuries on end, the author was described with strong colors, as a great figure, and every author was inspired by certain features of his character or evolved important episodes of his valor. Ode, sonnets, poems and novels were written, and many creators, inspired by this figure, created one-act dramas. Such works were written by the Spanish writers, including the well-known playwright Lope De Vega and several English playwrights such as Tomas Winkop and Uilliam Hauard. It is not known whether our playwright E. Haxhiademi was aware of any of these dramas before he wrote the tragedy "Scanderbeg" and whether they had served as creative support. All those who wrote about the Albanian national hero were based on Marlin Barletti's literary work. What about Haxhiademi, what historic and literary works did he used as a model for his work? Haxhiademi did not mention this but in the edition preface he clarifies that the subject was taken from our national history.

From the other side, although his works are intertextual in the ambit of the pre-existing texts, they represent various texts, with different internal structures features. Haxhiademi's literary work, as a variant of the literary system, is built on literary traces, codes and traditions created in the course of time in the literary inheritance and in addition to the 
Albanian ones. This makes his work, in a certain meaning, not to be totally independent but intertextual. The reading process has to do with the movement along texts belonging to the same system, the literary one. According to this viewpoint, the reception of Haxhiademi's dramatic literary text is revealed by understanding its relationships with other texts, not simply in addition to the Albanian ones, which also makes it intertextual. For example, his tragedy "Abel", is an intertext in rapport with the biblical narration, therefore, with a predecessor text. This intertextuality is shown in the biblical characters, in the ways they were perceived and the rapport between the author and the characters, in the narrative structure, in the speech rate, in the symbols belonging to biblical narration. What makes these texts intertextual is the reception of the relationships between their internal structures with the other texts which have preceded many narrative phenomenon in Haxhiademi's texts. In a certain way, there are artistic homology rapports among his texts and the preexisting structures

There is approximately one century dividing us from Haxhiademi's work, so the determination of intertextuality in his dramatic texts can better be linked with the rapport his work creates with the consecutive readers. According to the essence of this interpretation, various rapports between the artistic fiction of the work and the interpretation of its reception for the readers have been determined. According to the intertextuality theory, no text exists as single and autonomous since both the writer and reader's experience conditions its form and interpretation. His dramatic text offers multi-meaning possibilities. Traditionally, the qualified reader has meant the socialist reality in Albania, in a certain moment of its history. If the work is searched as a text which approaches the reader then its proportions change, since the readers are different in terms of the level of their artistic perception tastes. So, its reflexive reading continuously allows for a new way of attitude. Surely, the previous readers had a different appraisal from the present readers who have different perceptions.

Our appraisal is based on experiencing the author's dramatic text, as an intertext of the literary system as well as on the re-reading of its new meanings. Readers" appraisals also appear different, in terms of their abilities to understand the narration units and the prose as an intertext in its wholeness, and in rapport with other literary works as well as to read the text's entirety units in a new way. Relevance to intertextual reading does not mean that the text meaning is final, exhaustive; we can have more than one possible reading. Its meaning is in rapport with that of the other text it is connected with.

According to the theory of the literary intertextuality, the work of any writers does not have a finite meaning, with clear-cut boundaries but it remains open to the readers which study it. Actually, the author creates infinite artistic images. The latter remains always superior with the power it has on the readers because s/he is "unreachable" in the borders of its literary trace's system. In these terms even the intertextuality of $E$ Haxhiademi's work forces the scholars to speak about its values, understanding the work as a text in certain rapports with the other ones belonging to the literary system. The author's dramatic text creates a lot of meanings. Basing on the plurality of meanings we can determine the author's genuine artistic dimension.

The intertextual character of E Haxhiademi's work can be considered in two dimensions: in the horizontal and the vertical ones. In the horizontal dimension we discover the individuality of the artistic fiction, the way he perceives and builds the characters in "Abel" or "Scanderbeg", how he exploits the symbolic rapport, the dramatic situation, the trace elements etc. Moreover, in the vertical dimension such texts belong to a literary text existing before, therefore a specific literary system with peculiar structures and narrative means.

\section{Intertextual review of the tragedy "Abel".}

Tragedy "Abel' can be subject to that kind of intertextual review which has a relationship with a previous text, with the biblical text in the Old Testament, Mosses First Book. The tragedy "Abel", is the simplest of E. Haxhiademi's work in terms of its subject and the dramatic action, but it is great and complicated in terms of the psychological analyses. The biblical symbolism in Haxhiademi's text makes the reader to look into the rapports, father-mother, children-parents, brother-brother. In Haxhiademi's dramatic text as well as in the biblical narration from the Old Testament, certain figures and themes, playing the role of the "isotopic crucifixion" that is the junction of the two or more isotopies in which one can notice aspects of semantic deception, (Pozzato, P.M. 2009) Let us review basing on the isotopic ambiguity:

According to the bible, in the Old Testament, Chapter IV of Mosses Book, Eve confesses about Adam's sons: "Adam, too, knew his wife, Eve, she was conceived pregnant and gave birth to Cain, and said: I gained a male by God. And she went on this way and gave birth to Abel:, Cain's brother. Abel became a shepherd, whereas Cain became e farmer. However, it happened that according to the customs of that time, Cain immolated fruit trees as sacrifices to God whereas Cain immolated his lambs and dairy. God liked Abel's sacrifice whereas God didn't like Cain and his sacrifice. 
This made Cain angry and he was all frowns. And God spoke to Cain: Why are you angry? Why are you all frowns? If you believe, you will be liked. If you don't believe the fault is at the doorstep waiting for you there, but you should dominate it. Then Cain spoke to his brother, Abel. When they were together on their land plot Cain rose against his brother and killed him. Then God spoke to Cain: Where is your brother? He answered: I don't know. Why, should I look after him? Then God spoke again: What have you done? Your brother's blood is calling me from the soil!.

According to the bible, the malediction of the "prohibited apple" should have befallen on the just created Adam and Eve's family. This divine fatal will was realized when the two brothers immolated their 'toil's fruit as sacrifice to God. God didn't accept Cain's vegetarian sacrifice. Envy immersed between the two brothers. Cain murdered Abel and got cursed by God so that the land plot does not yield much production.

Whole-scale isotopes are found in both texts, deriving from them as a whole. In the biblical texts there are biblical whole-scale isotopes, (in divine aspect), in the dramatic text there are whole-scale isotopes (in terrestrial aspect). Also, certain figures and themes play the role of isotopy intermediates. In the texts we are looking into, isotopies are alternative. In the second dramatic text occurs the alteration process. Events descend from the divine ambit to the terrestrial one. This way of composing narration helps the author to transmit important morals in the family, social, national and international ambit. The isotopic parallelism helps the reader to draw parallels between the biblical prehistory and the phenomenon, ideas and the problems featuring the reality of his own time.

In the following inquiry, the expression units, (lexemes), have been presented in italics, whereas the meaning units with normal letters. In both texts there are expressions that are perfectly approaching both isotopies. In the biblical text, in the divine ambit, lexemes Adam and Eve, Abel and Cain, sacrifices, envy, jealousy and love, Providence's malediction, death, orient us toward these meanings.

Adam and Eve, the first living humans on earth, created from God, from the dust of the soil, possessors of all miracles, created by God. The first deities in the divine family. First life sinners on the earth, (their greed, eating from the tree that make them understand evil and good, the snake's deception, Satan's tool). Adam, the first human made for God, (he belonged to the earth but still hanging on the sky). Eve- the mother of all living things, the most perfect human being in the divine life. Abel and Cain, first predecessors of the first divine family, Abel is a shepherd, whereas Cain is a farmer. Inequality in the division of jobs incites the greed of human feelings. Abel was oriented towards positive feelings whereas Cain towards negative ones. Sacrifices, the immolations the two brothers offer to God. God did not accept Cain's sacrifice, but liked Abel's sacrifice. Abel's immolation was appraised from its quantity as a sign of devotion, love, commitment to God. Divine inequality in unequal proportions of love between the two brothers. Envy and Jealousy, feelings oriented towards negativity as result of the differentiated divine love between brothers. Creator's malediction, because of the first human dwellers on the earth, Adam and Eve, in the Eden's garden. God's warning for the sin's kingship in the life of humans. The first predecessors will be inheritors of the initial sin. Incited by jealousy, envy, anger, hatred, Cain kills Abel. The death in the divine ambit, in the biblical narration, is presented as a whole-scale loss whereas in the terrestrial ambit it has been presented as a solution. This is, therefore, the descent from the divine to the terrestrial ambit. (Hamiti, S. 2009).

In the divine ambit, the ruining of the balances in the divine life brought the fratricide. Cain, the first murderer paid what he did very dearly. Cain, the initial sin first inheritor and sufferer. Abel, the first martyr, died because of his belief. The malediction brought tragedy to the divine society.

Alteration in tragedy: The work's subject has been taken from biblical mythology. In its foundations stand motifs taken from the Old Testament. The story told has been inspired from the legend on public figures. The approach of the drama subject to the biblical myth has revealed various and essential landmarks. Biblical facts have been changed by the author conform his own individual style. Therefore the biblical subject has been changed considerably. The biblical myth utilized by E. Haxhiademi in his tragedy "Abel", has been changed and worked out conform the spirit of his own time. The utilization of this mythological subject and the biblical motif serves to treat important ethical, moral social and political problems. The author does not narrates about the myth, but created an artistic work, created characters and conflicts by means of which important morals will be transmitted on the course of the time.

The subject of this tragedy the protagonists are the first humans on earth. Adam and Eve, authors of the first family argue about the ruined harmony among people, for the broken peace in the Act I, Scene I. The scene appears shocking, it reveals the dawn of the humans history, when the biblical God had just started to realize the ideal world. At this moment a tragic occurrence happened, people lost the God. The first man and the first woman failed to realize their potentials and the sinful history will follow the other descendants. In E. Haxhiademi's tragedy, with utterly mythical subject, the donations are offered to parents, other than the biblical narration in which sacrifices have been offered to Gods. The divine element has so been avoided, and the biblical tragedy became a family tragedy. The lack of the Gods 
presence and their participation into the dramatic action does not support a mythological treatment, but a historic and realist one. (Matraxhiu, B. 1991). Abel spoke very respectfully for the Divine Father on the Altar, on whom he believed wholeheartedly. Cain also, knelt and sent some words to God, but there were no thanks, gratitude, and belief in his heart. Cain has been given a sincere but rude character. The detail regarding the disdainful sacrifice and the welcomed one incites Cain's jealousy, for the differentiated parental love in tragedy and the differentiated divine love in the biblical narration. (Plasari, A. 1991) The malediction, in a terrestrial ambit, the Adam's fatherly malediction to Cain brought the drama into the terrestrial society. The death act in the terrestrial ambit, should be understood as a solution in tragedy. In the terrestrial, family, and national ambit the ruining of the balances in the terrestrial life brought fratricide in the family ambit and the civic war in the national and international ambit.

\section{Conclusions}

The aforementioned review, the analyses dimensions in the horizontal and vertical ambit, which intended to determine the intertextual character of $E$ Haxhiademi's text, do not add more artistic values to the author's texts. This way of review intends to reveal the interdependence of his texts with the pre-existing ones, and to reveal the real values, often modest ones. The intertextual review cannot be an analysis on its own, but a scientific way to determine the authentication and the real values of $\mathrm{E}$. Haxhiademi's artistic work.

\section{References}

Matraxhiu, B. (1991). Critique to tragedy and the tragedy of the critique. . Magazine Nëntori, 7, 93-116.

Plasari, A. (1991) The ideology of love facing the ideology of hatred. Magazine Nëntori, 1, 79.

Reference to a book:

Dado, F. (2006).Intuition and critical conscience, Onufri.

De Beaugrande, R. A.,\& Dressler , W. U. (1994).Introduzione alla linguistica testuale. Bologna: il Mulino.

Kristeva, J.(1999).Dictionary of Literary Terms \& Literary Theory. Penguin Books.

Onega, S., \& Landa, G. A.J. ( 1996 ). Narratology.London.

Reference to a chapter in an edited book:

Hamiti, S. (2009).Albanian modern literature .Fratricide, Abel and Cain. (pp 328-337).Tiranë: UET-press

Pozzato, P.M . (2009).Text semiotics. Schematic organization. pp 88-97 ). Tiranë: shblu. 